\title{
DÜBLIN
}

Technological University Dublin

ARROW@TU Dublin

\section{Quality of Shredded Carrots as Affected by Packaging Film and Storage Temperature}

\author{
Catherine Barry-Ryan \\ Technological University Dublin, Catherine.Barryryan@tudublin.ie \\ David O'Beirne \\ University of Limerick, David.obeirne@ul.ie
}

Follow this and additional works at: https://arrow.tudublin.ie/schfsehart

Part of the Food Science Commons, and the Plant Sciences Commons

\section{Recommended Citation}

Barry-Ryan, C., O'Beirne, D.:Quality of Shredded Carrots as Affected by Packaging Film and Storage Temperature.Journal of Food Science, 65 (4), pp. 726-730. doi:10.1111/j.1365-2621.2000.tb16080.x

This Article is brought to you for free and open access by the School of Food Science and Environmental Health at ARROW@TU Dublin. It has been accepted for inclusion in Articles by an authorized administrator of ARROW@TU Dublin. For more information, please contact arrow.admin@tudublin.ie, aisling.coyne@tudublin.ie, gerard.connolly@tudublin.ie.

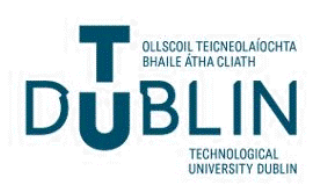




\title{
Quality of Shredded Carrots as Affected by Packaging Film and Storage Temperature
}

\author{
Journal of Food Science, 65, 726-730. \\ Catherine BARRY-RYAN1, J.M. PACUSSI2, D. O'BEIRNE2 \\ 1School of Food Science and Environmental Health, Dublin Institute of Technology (DIT), Cathal \\ Brugha, Dublin 1, Ireland. catherine.barryryan@dit.ie. \\ 2. Dept of Life Sciences, University of Limerick, Limerick.
}

ABSTRACT: Different packaging films and storage temperatures were used to establish a range of equilibrium modified atmospheres for storage of shredded carrots. Quality and storage-life of the packaged shredded carrots were determined using sensory evaluation, microbial counts, and a range of physical tests. Minimal processing steps such as peeling and shredding caused physical damage, physiological stress, and enhanced microbial growth, leading to a reduced shelf life when compared to the whole vegetable. A P-plus microporous film $\left(\mathrm{CO}_{2}\right.$ permeability of $2910_{3} \mathrm{~mL} . \mathrm{m}_{2} . \mathrm{d}_{1}$.atm ${ }_{1}$ ) was the most suitable for the storage of shredded carrots. Findings indicated that deterioration in these products was triggered by the depletion of oxygen more than by the rise in carbon dioxide.

Key Words: carrots, shredded, modified atmosphere packaging, film, permeability, storage temperature

\section{Introduction}

Modified atmosphere packaged

(MAP) shredded carrots (Daucus

carota L., cv. Nantaise des Sables) are an increasingly popular product, but sales are restricted due to rapid deterioration during storage. The product tends to become slimy, lose firmness, and develop off-odors, characteristics of anaerobic catabolism, due to very high respiration rates and susceptibility to microbial spoilage (Chantry and Vlandas 1988) Shredding cuts through cells, leaving large areas of internal tissue exposed and disrupting some subcellular compartmentalization. Stress response reactions lead to increased respiration rates and to the synthesis of lignin (Bolin and Huxsoll 1991b). For example, Selman (1993) demonstrated a 7 -fold increase in respiration rate due to shredding. Matching these high respiration rates with highly gas permeable packaging films represents a significant technical challenge.

Shredding facilitates contamination by epithelial microflora, and leaked nutrients provide richer substrates than available in intact tissue (Carlin and others 1989). Surface dehydration and moisture loss generally are also increased by minimal processing (Cisneros-Zevallos and others 1995). Reduced shelf life is caused by a combination of loss in firmness and production of slime and offodors (McLachlan and Stark 1985; Carlin and others 1989).

The impact of processing and the vegetable stress reactions may be minimized by refrigerated storage and suitable modified atmosphere packaging. MAP fresh produce requires that a narrow range of gas concentrations be maintained in a package, typically $3 \%$ to $10 \%$ oxygen (O 2 ) and $3 \%$ to $10 \%$ CO 2 (O'Beirne 1990). This is achieved by means of a dynamic interaction between the respiring produce, the gas permeability of the packaging film, and environmental conditions such as storage temperature (Exama and others 1993).

The objective of this study was to determine the effects of equilibrium MAs (through manipulation of film permeabilities and storage temperature) on the quality and storage life of MAP shredded carrots. A range of physical and microbial changes thought to be responsible for deterioration of carrot quality was monitored (McLachlan and Stark 1985; Carlin and others 1989, 1990).

\section{Results and Discussion}

An equilibrium modified atmosphere (EMA) was reached in most packs by d 3 to 5 of storage. $\mathrm{CO}_{2}$ levels ranged from approximately $30 \%$ in OPP bags to approximately $4 \%$ in the OSM packs with the hydrophilic coating (Fig. 1). The OSM film is hydrophilic and has a high selectivity $\mathrm{P} \mathrm{CO}_{2} / \mathrm{P} \mathrm{O}_{2}$ resulting in low $\mathrm{O}_{2}$ and $\mathrm{CO}_{2}$ atmospheres. The microporous films ( $P$ plus) have EMAs where combined oxygen and carbon dioxide levels remain at about $21 \%$. The levels of $\mathrm{CO}_{2}$ in the other bags were dependent on film permeability; high permeability resulted in low $\mathrm{CO}_{2}$ levels. CO 2 levels were also affected by storage temperature; levels were lower at $3 \mathrm{C}$ compared with $8 \mathrm{C}$. The equilibrium carbon dioxide levels in OPP and DP bags were sufficiently high to cause physiological damage. For example, Brecht (1980) found that $\mathrm{CO} 2$ levels above $1 \%$ induced brown stain in Crisphead lettuce and that levels above $15 \%$ produced off-flavors. $\mathrm{O} 2$ levels in the bags made from the P-plus 2 film, approximately $18 \%$, were too high to give a technically beneficial EMA. O2 levels reached $1 \%$ in all other bags (about $0.9 \%$ argon included in oxygen values due to limitations of CTR1 column), except in bags made from P-plus film 1 , where levels equilibrated at about $5 \%$ (Fig. 1). Excessively low levels of $\mathrm{O}_{2}$ (below $1 \%$ ) can result in anaerobic respiration and the development of off-odors (Ulrich 1975). Absence of O2 could facilitate growth and toxin production by human pathogens (Finn and Upton 1997).

This range of EMAs, resulting from the various film permeabilities and storage temperatures, had direct effects on the quality of shredded carrots and was monitored by the sensory panel. Highest appearance scores were given to product packed under 10\% CO 2 and $10 \% \mathrm{O}_{2}(\mathrm{P}$ plus film 1) at $3 \mathrm{C}$ and under $28 \% \mathrm{CO}_{2}$ and $1 \% \mathrm{O}_{2}$ (OPP) at $8 \mathrm{C}$ (Fig. 2). Samples stored under $3 \% \mathrm{CO}_{2}$ and $<1 \% \mathrm{O}_{2}$ (OSM) received lowest appearance scores (p0.05, Fig. 2), irrespective of temperature.

Highest aroma scores were given to product packed in the $\mathrm{P}$-plus films, with no significant difference due to permeability. Carrots stored under $16 \% \mathrm{CO}_{2}$ and

$1 \% \mathrm{O}_{2}(\mathrm{DP})$ received the lowest aroma scores $(\mathrm{p}<0.05)$, and under $3 \% \mathrm{CO} 2$ and

$1 \% \mathrm{O}_{2}$ (OSM) received intermediate aroma scores. Scores for carrots stored un$1 \% \mathrm{O}_{2}$ (OPP) droppedder 28\% CO 2 and substantially from d 7 onwards, corresponding to the excessively high $\mathrm{CO} 2$ levels. Product stored at $3{ }^{\circ} \mathrm{C}$ had significantly higher appearance and aroma scores (p0.05) from d 1 than those 
stored at $8 \mathrm{C}$, and the rate of decline in quality was also slower (Fig. 2). This may be due to the fact that physiological activity, for example the respiration rate, and microbial growth rates were slowed down at the lower temperature (Bolin and Huxsoll 1991a; Krahn 1977).

Total aerobic (TA) counts were significantly higher in the packs stored at $8 \mathrm{C}$ than at $3 \mathrm{C}$ (data not shown). This effect of temperature was reported previously by Brackett (1987) and Wiley (1994). Shredded carrots stored at $8 \mathrm{C}$ had initial loads of total aerobes (TA) and yeasts and molds (YM) of approximately 6 Log $\mathrm{cfu} / \mathrm{g}$ and lactic acid bacteria of 2.2 to 3.7 Log cfu/g. All counts rose to 8 to $9.7 \mathrm{Log}$ $\mathrm{cfu} / \mathrm{g}$ by the end of storage. Microbial load enumeration showed that shredded carrots stored under an EMA of 3\% $\mathrm{CO} 2$ and $18 \% \mathrm{O}_{2}$ (P-plus film 2) had the highest loads for TA and YM. As these atmospheres contained higher oxygen levels, they supported higher aerobic microbial growth. Packs with EMAs of $10 \% \mathrm{CO} 2$ and $10 \% \mathrm{O}_{2}$ (P-plus film 1) and 16\% CO 2 and $1 \% \mathrm{O} 2$ (DP) had TA loads $0.5 \mathrm{Log}$ cfu/g lower from d 5 onwards (p0.05). Carrots stored under EMAs of $28 \%$ CO 2 and $<1 \%$ $\mathrm{O}_{2}$ (OPP) and $3 \% \mathrm{CO}_{2}$ and $1 \% \mathrm{O}_{2}$ (OSM) had the lowest TA loads (Fig. 3a), due to the high $\mathrm{CO} 2$ levels. Lowest YM counts were recorded for grated carrots packaged in $28 \% \mathrm{CO} 2$ and $1 \% \mathrm{O}_{2}$ (OPP) and $16 \% \mathrm{CO}_{2}$ and $1 \% \mathrm{O}_{2}(\mathrm{DP})$, with no significant difference between the 2 films. Higher YM loads, 0.5 Log cfu/g, were recorded on carrots packaged under $3 \%$ $\mathrm{CO}_{2}$ and $1 \% \mathrm{O}_{2}$ (OSM) and $10 \% \mathrm{CO}_{2}$ and $10 \% \mathrm{O}_{2}$ (P-plus film 1), but there were no

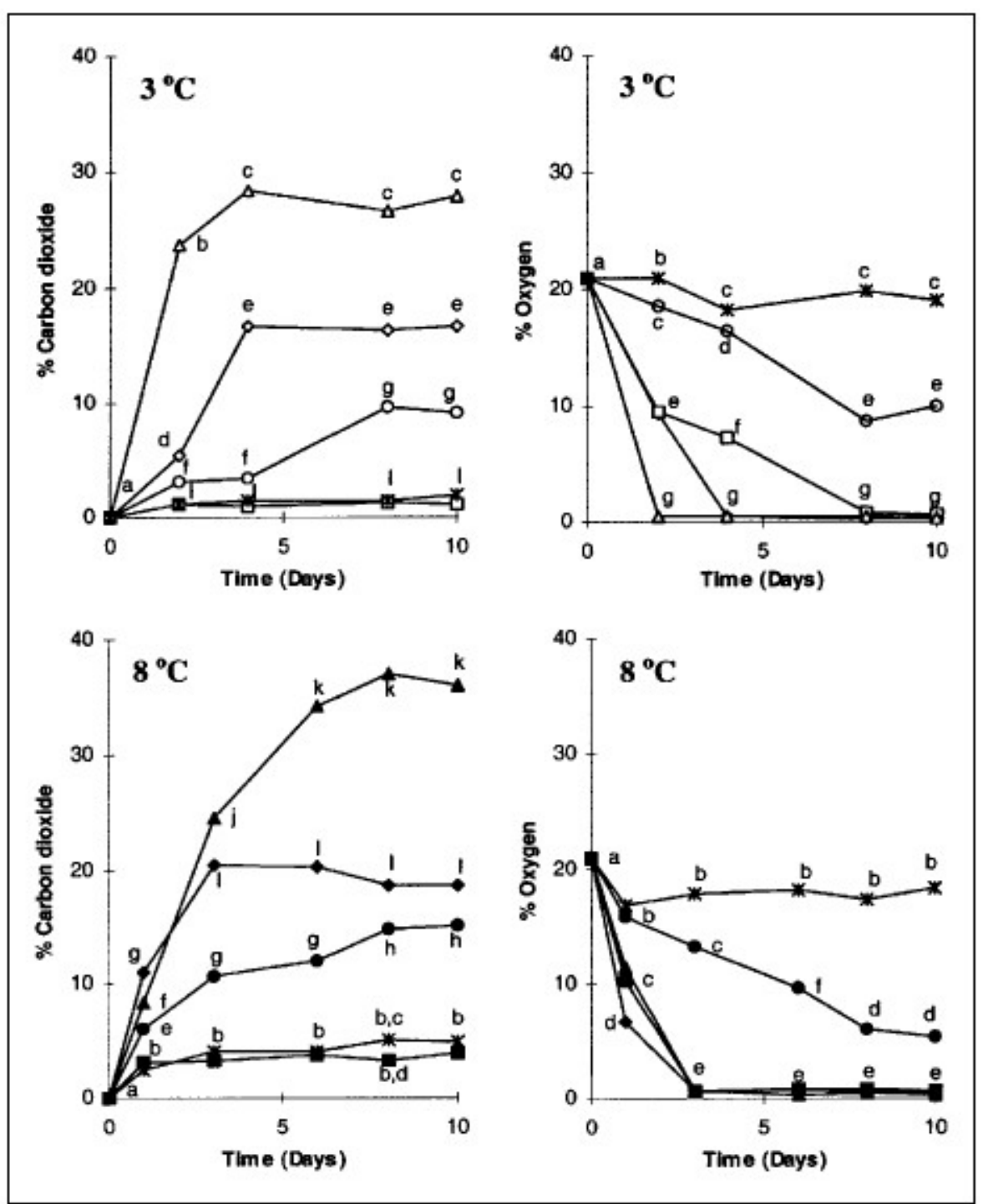

significant difference between the 2 ( $p$ 0.05 , Fig. 3b). Loads of lactic acid bacteria (LAB) increased substantially during storage, coinciding with the rising levels of $\mathrm{CO}_{2}$, but with little difference between packs (Fig. 3c).

Firmness values for shredded carrots increased slightly in all packs up to $d 4$, continuing to increase or stabilize up to $d$ 6. After d 8 firmness began to decrease, except for carrots stored under $16 \% \mathrm{CO}_{2}$ and $1 \% \mathrm{O}_{2}$ (DP) film, which showed a rapid decrease only $4 \mathrm{~d}$ after production (3 C, Fig. 4). Firmness increases over storage due to the drying out of the shredded carrots and may be partly caused by lignin production. Decreases in firmness during storage may be a result of cellular breakdown due to both microbial growth and biochemical activity. Firmness measurements were highest for carrots stored in the P-plus films and lowest for carrots stored under $16 \% \mathrm{CO} 2$ and

$1 \% \mathrm{O}_{2}(\mathrm{DP})(\mathrm{p} 0.05)$. However, the effects of a $28 \% \mathrm{CO}_{2}$ and $1 \% \mathrm{O}_{2}$ EMA (OPP film) on texture depended on storage temperature. At $8 \mathrm{C}$ there was a decline in texture from d 3 onward, but at the lower temperature (3 C), this was delayed until d 8 (Fig. 4). Similar findings were reported by Bolin and Huxsoll (1991a) when they examined the effect of storage temperature on the firmness of shredded lettuce.

Measurable exudate was in the range 5 to $7 \mathrm{~g} / 100 \mathrm{~g}$ fresh weight on $\mathrm{d} 1$ and then decreased up to $d 8$, after which it began to stabilize in most packs (Fig. 5). There were small differences due to the $1 \% \mathrm{O} 2 \mathrm{MA}$ that developed; $3 \%$ CO 2 and (OSM film) had much lower levels, and packs with EMAs of $28 \% \mathrm{CO} 2$ and $1 \%$ $\mathrm{O} 2$ (OPP) had higher levels up to $d 6$ ( $p$ 0.05 ). Exudate is a measure of cellular sap released; falling exudate levels during storage are presumably due to loss of water vapor, and the lower levels in OSM film are accounted for by the high permeability of this film, losing moisture at a rate of $3,500 \mathrm{~g} / \mathrm{m} 2.24 \mathrm{~h}$. Similar trends were observed at $3 \mathrm{C}$, but overall exudate levels were $1 \mathrm{~g}$ lower than at $8 \mathrm{C}$ due to greater drying out of the product at the higher temperature. Carlin and others (1989) observed similar trends in exudate levels for shredded carrots.

There was no statistical change in tis sue $\mathrm{pH}$ up to $\mathrm{d} 3$ of storage at $3 \mathrm{C}$; this fall was delayed until after $\mathrm{d} 6$ at $8 \mathrm{C}$ for DP-, OSM-, and OPP-stored carrots, after which it fell in all packs (Fig. 6). The $\mathrm{pH}$ levels were lower the higher the $\mathrm{O} 2$ levels within the packs of carrots for all films, except DP ( $1 \% \mathrm{O}_{2}$ ). pH levels were, therefore, lowest in bags made from the high permeability P-plus film 2, and by

Fig. 1-The effects of film type on the modified atmosphere within packs of shredded carrots. OPP ( ), DP film with hydrophilic coating ( ), OSM film ( ), and P-plus films 1 ( ) and 2 ( ). Closed symbols for packs stored at $8^{\circ} \mathrm{C}$ and open symbols for packs stored at $3^{\circ} \mathrm{C}$. (Different letter denotes statistical difference at $p<0.05$.) 


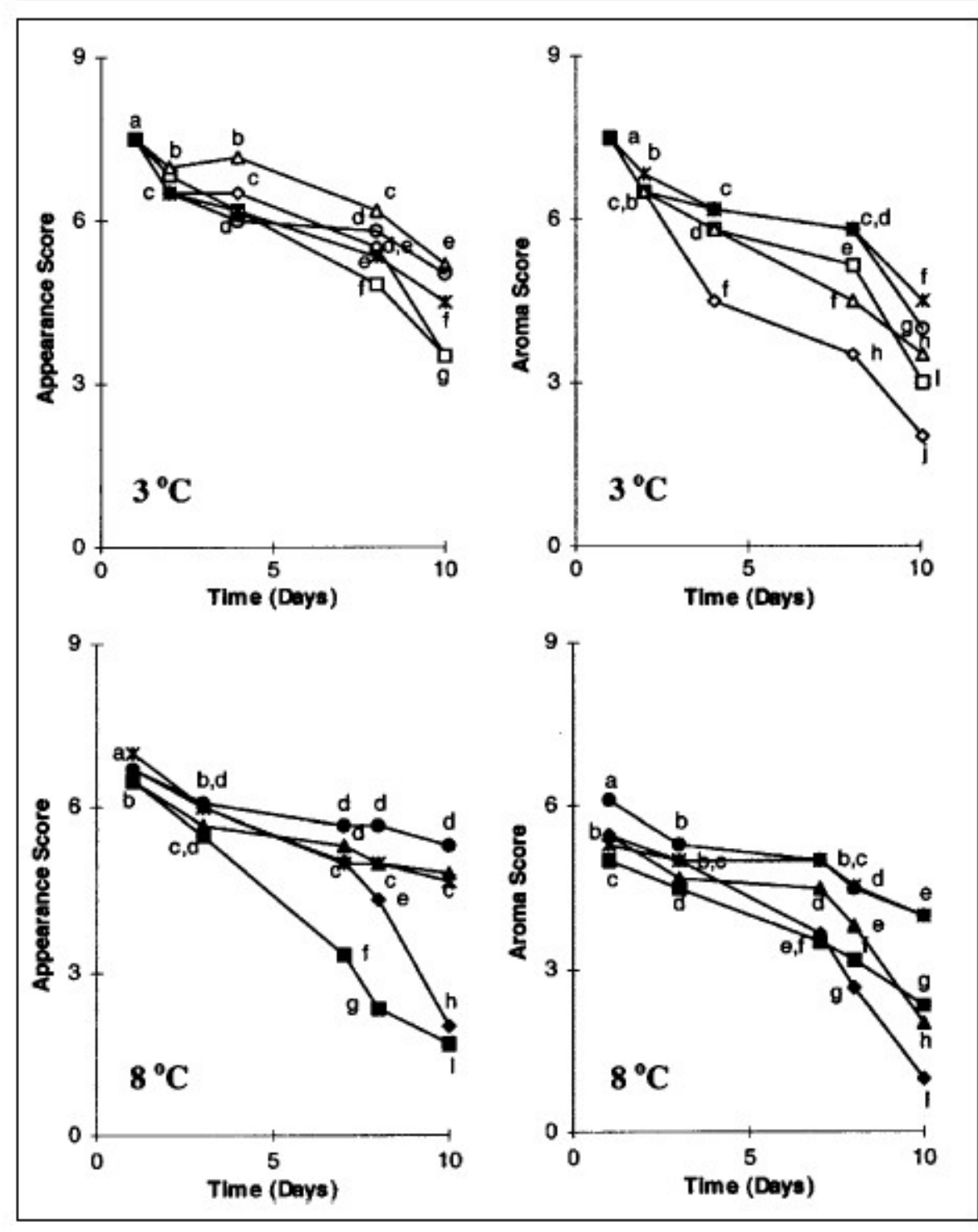

Fig. 2-The effects of film type on the sensory scores of MA-packaged shredded carrots. OPP ( ), DP film with hydrophilic coating ( ), OSM film ( ), and P-plus films 1 ( ) and 2 ( ). Closed symbols for packs stored at $8{ }^{\circ} \mathrm{C}$ and open symbols for packs stored at $3{ }^{\circ} \mathrm{C}$. (Different letter denotes statistical difference at $\mathrm{p}<0.05$.)

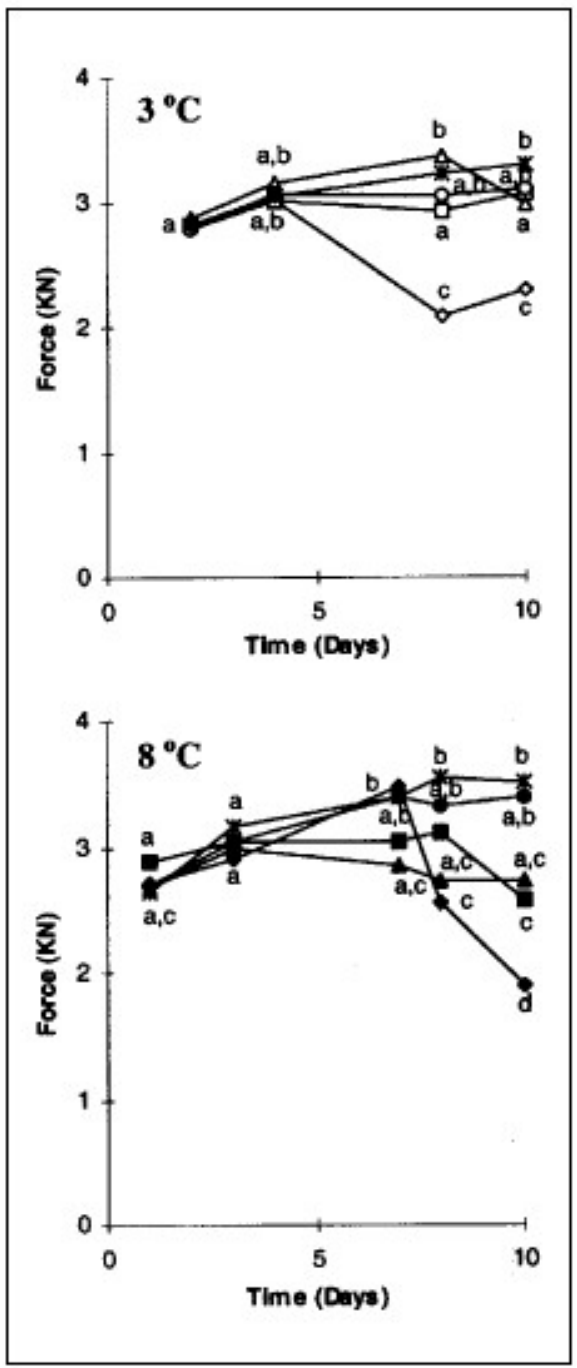

Fig. 4-The effects of film type on the texture of MA-packaged shredded carrots. OPP ( ), DP film with hydrophilic coating (), OSM film (), and P-plus films 1 ( ) and 2 ( ). Closed symand P-plus films 1() and 2() . Closed symfor packs stored at $3^{\circ} \mathrm{C}$. (Different letter denotes statistical difference at $p<0.05$.)
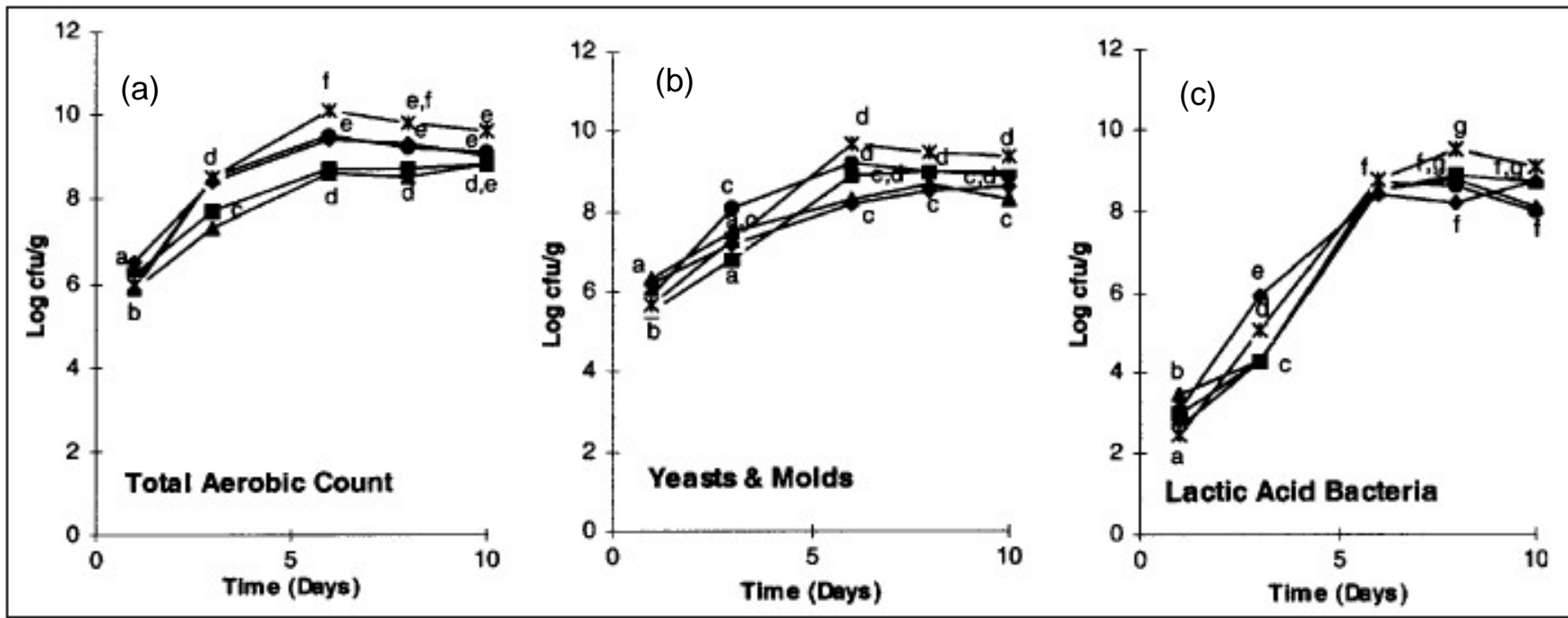

Fig. 3-The effects of film type on the microbial load of MA-packaged shredded carrots. OPP ( ), DP film with hydrophilic coating ( ), OSM film (), and P-plus films 1 () and $2\left(\right.$ ), stored at $8{ }^{\circ} \mathrm{C}$. (a) Total aerobic counts, (b) yeasts and molds, and (c) lactic acid bacteria counts. (Different letter denotes statistical difference at $p<0.05$.). 


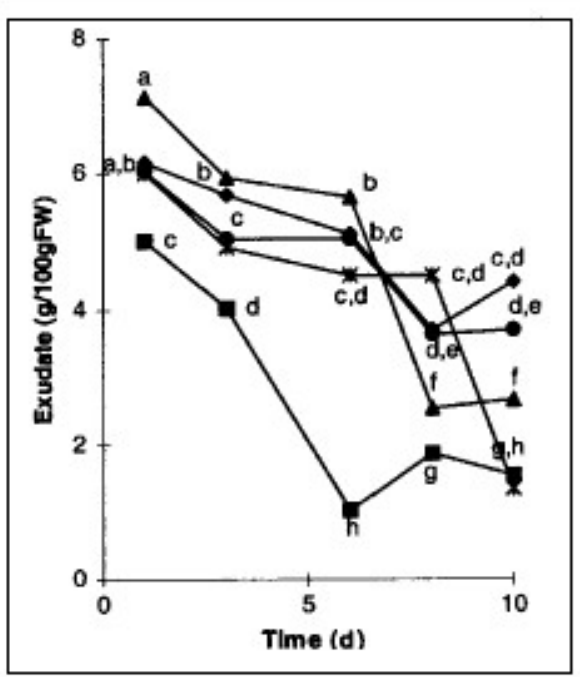

Fig. 5-The effects of film type on the exudate produced by MA-packaged shredded carrots. OPP (), DP film with hydrophilic coating (), OSM film (), and P-plus films 1 () and 2 (), stored at $8{ }^{\circ} \mathrm{C}$. (Different letter denotes statistical difference at $p<0.05$ )
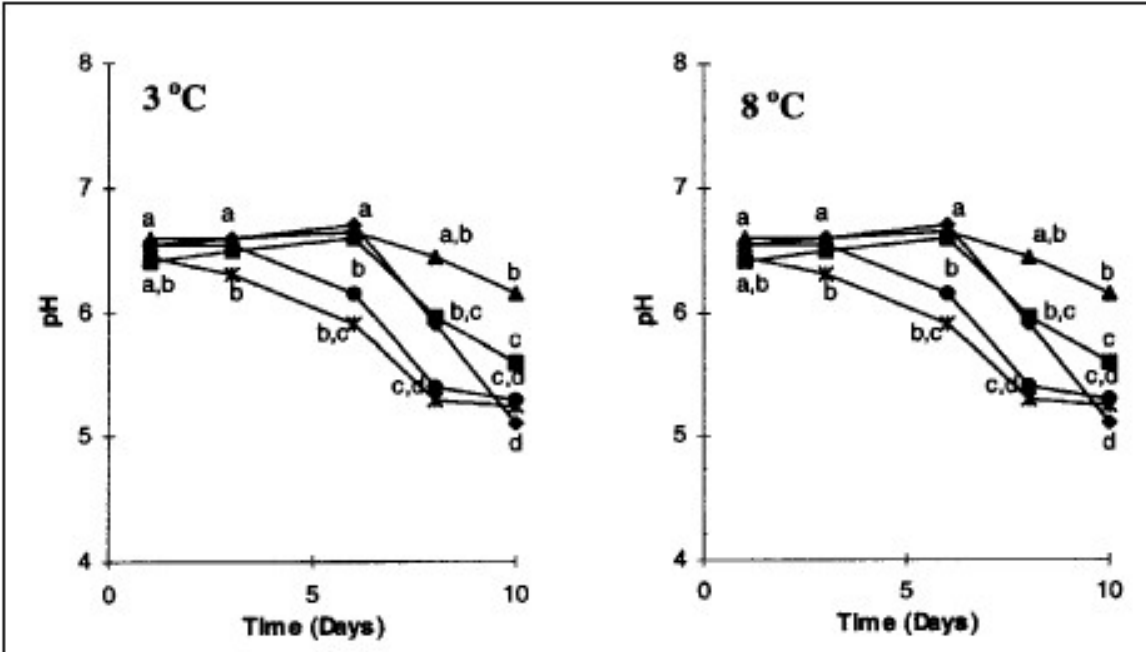

Fig. 6-The effects of film type on the $\mathrm{pH}$ of MA-packaged shredded carrots. OPP ( ), DP film with hydrophilic coating ( ), OSM film ( ), and P-plus films 1 ( ) and 2 (). Closed symbols for packs stored at $8{ }^{\circ} \mathrm{C}$ and open symbols for packs stored at $3^{\circ} \mathrm{C}$. (Different letter denotes statistical difference at $p<0.05$.

OPP and DP), or high $\mathrm{O}_{2}$ (P-plus film 1) levels and low $\mathrm{CO}_{2}$ levels combined with both high $\mathrm{O}_{2}$ (P-plus film 2) and low $\mathrm{O}_{2}$ levels (OSM) (Fig 1). Evaluation of the sensory quality and determination of the deterioration processes in grated carrots implied that anaerobic catabolism was a major factor, as off-odors, microbial loads, softening, and slime production were all characteristic of fermentation. It appeared that this type of deterioration occurred more rapidly under reduced levels of $\mathrm{O}_{2}$ than by elevated levels of $\mathrm{CO}_{2}$

\section{Conclusions}

Deterioration in MA grated carrots was confirmed to be caused by slime production, loss of firmness, and the development off-odors-characteristics of anaerobic catabolism. This deterioration occurred more rapidly with the depletion of oxygen than by the rise in carbon dioxide in the package. A film with similar permeabilities to oxygen and carbon dioxide was more suitable for the storage of shredded carrots. with a range of $\mathrm{CO}_{2} 3 \%$ to $35 \%$ and $\mathrm{O}_{2} 1 \%$ to $20 \%$ : high $\mathrm{CO}_{2}$ levels combined with low $\mathrm{O}_{2}$

\section{Materials and Methods}

\section{Plant material}

A French carrot cultivar, Nantaise des Sables, was used to produce MAP shredded carrots. The carrots had been washed by the producer. Medium-sized roots ( 3 to $4 \mathrm{~cm}$ dia), free of defects were used.

\section{Slicing and processing}

Carrots $(10 \mathrm{~kg})$ were abrasion peeled using a Metcalfe electric abrasion peeler, Model 10 (Metcalfe Catering Equipment

Ltd., Gwynedd, England) with a fine-grain peeling plate. Peeled carrots were then topped and tailed using a sharp knife and washed for 5 min with chlorinated water (100 ppm free chlorine, $\mathrm{pH}$ 6.9) followed by a tap-water rinse. They were left to drip-dry for 15 min in a perforated cage. Carrots were shredded $(1.5 \mathrm{~mm} 1.5 \mathrm{~mm}$ strips) using a Sammic CA300 vegetable processing machine (Sammic, Barcelona Spain) equipped with a grating disk and spun for $30 \mathrm{~s}$ using a salad spinner (200 rpm).

Shredded carrots were then packaged in $200 \mathrm{~g}$ lots in bags, $30 \mathrm{~cm} 20 \mathrm{~cm}$, prepared from various packaging films (see Table 1). Bags were sealed using a Multivac A300 packaging machine (Multivac, Wolfertschwenden, Germany). The bagged products were stored at 3 or $8 \mathrm{C}$ and evaluated during storage. These temperatures were chosen for investigation as the recommended storage temperature for such products is 2 to $6 \mathrm{C}$, but ready-touse products are often stored at higher temperatures in normal retail distribution (Carlin and others 1990).

\section{Sensory evaluation}

Analytical sensory evaluation was used to discriminate between the appearance and aroma of shredded carrots packaged in different films (BarryRyan 1996). A panel of 10 judges, ages 22 to 30 years ( 8 female and 2 male, all members of the UL Food Science Research Centre), with sensory evaluation experience, were trained in discriminative evaluation of shredded carrots. The carrots used during the training sessions, every second d for $1 \mathrm{mo}$, had been subjected to various storage treatments and times. Fresh carrots, from the batch used for processing, were used as the control (score9). The training panel was shown the effects of storage over $10 \mathrm{~d}$ in air in contrast to a modified atmosphere. The effects of storage temperatures $(3,8$, and $20 \mathrm{C})$ and time $(10 \mathrm{~d})$ on the grated carrots were also shown during the training sessions. The products were presented in groups, by sample d, to a single sensory judge at a time on a white laboratory bench in an odor-free fluorescent lit food laboratory. The individual products were scored for appearance and aroma on a scale of 1 to 9 , where 1 very poor, 4 to 5 fair, and 9excel- 
lent. Judges relied on their training experience to score products. Sensory evaluation was used to determine the shelf life of these products, as scores of 5 or below were taken to indicate the end of shelf life. The entire experiment was repeated 3 times, and the sensory scores presented as the overall means.

\section{Exudate production}

Exudate was quantified by the method described by Carlin and others (1990). A sample (4 g) was placed between 2 filter papers (Whatman No. 541, $5 \mathrm{~cm} \mathrm{dia}$ ), and a force of $10 \mathrm{~kg}$ was applied for $10 \mathrm{~s}$. The measurement was repeated 4 times, and mean values were expressed as g exudate / $100 \mathrm{~g}$ fresh weight.

\section{Shear testing}

A Universal Testing machine, model 4302 (Instron, High Wycombe, U.K.) fitted with a Kramer Shear Cell 4801, was used to measure the peak shear force required to shear $50 \mathrm{~g}$ shredded carrots. A crosshead speed of $75 \mathrm{~mm}$.min 1 and a full-scale force of $5 \mathrm{kN}$ were used.

\section{Microbial enumeration}

Packages from each treatment were sampled during storage at regular intervals. The product $(40 \mathrm{~g})$ was added to $360 \mathrm{~mL}$ sterile peptone water and blended (2 min) at high speed in a Waring Blender (New Hartford, Conn., U.S.A.)

Serial dilutions (10 1 to 106 ) were car-

\section{References} Bolin HR, Huxsoll CC. 1991b. Control of minimally

Cisneros-Zevallos L, Saltveit ME, Krochta JM. 1995. analysis. J Food Sci 57:1168-1172, 1184

Film

Oriented polypropylene (OPP, $35 \mathrm{~m}$ )

Pebax film (OSM)

Polyether block amide (DP, 35 m)

P-plus film 1

P-Plus film 2

*when hydrated

1with a hydrophilic coating
Barry-Ryan C. 1996. Factors in deterioration of vegetables processed using novel mild techniques [PhD thesis]. Limerick, Ireland: University of Limerick. $158 \mathrm{p}$.

Bolin HR, Huxsoll CC. 1991a. Effect of preparation procedures and storage parameters on quality retention of salad-cut lettuce. J Food Sci 56:60-64. processed carrot (Daucus carota) surface discoloration caused by abrasion peeling. J Food Sci 56:416-418. Brackett RE. 1987. Microbiological consequences of minimally processed fruits and vegetables. J Food Quality 10:195-206.

Brecht PE. 1980. Use of controlled atmospheres to retard deterioration of produce. Food Technol 34:45-50.

Carlin F, Nguyen-the C, Cudennec P, Reich M. 1989 Microbiological spoilage of ready-to-use grated carrots Sci Aliments 9:371-386.

Carlin F, Nguyen-the C, Hibert G, Chambroy Y. 1990. Modified atmosphere packaging of fresh 'ready-to-use' grated carrots in polymeric films. J Food Sci 55:1033-1038

Chantry JL, Vlandas S. 1988. La 4eme gamme.

Opinion des consommatrices. Infos-CTIFL. Hors-serie "4eme gamme": 65

nism of surface white discoloration of peeled (minimal ly processed) carrots during storage. J Food Sci 60:320-323, 333.

Exama A, Arul J, Lencki RW, Lee LZ, Toupin C. 1993. Suitability of plastic films for modified atmosphere packaging of fruits and vegetables. J Food Sci 58:1365-1370.

Finn MJ, Upton ME. 1997. Survival of pathogens on modified-atmosphere-packaged shredded carrot and cabbage. J Food Protect 60:1347-1350.

Krahn TR. 1977. Improving the keeping quality of cut head lettuce. Acta Hort 61:79-92.

McLachlan A, Stark R. 1985. Modified atmosphere packaging of selected prepared vegetables. Technical memorandum no. 412. Chipping Campden, U.K. Campden

Food Preservation Research Association p 1-20. O'Beirne D. 1990. MAP of fruits and vegetables. In: Gromley TR, editor. Chilled Foods: The State of the Art. New York: Elsevier Applied Science. p 183-191. Selman JD. 1993. Practical experiences of sensory investigations into the packaging of vegetables. Packaging Technol Sci 6:183-193. Shamaila M, Powrie WD, Skura, BJ. 1992. Sensory evaluation of strawberry fruit stored under modified everiptive Mecha-

Table 1—Permeability to oxygen and carbon dioxide of films used to packaged shredded carrots

$$
\text { Permeability (mL.m-2.d-1.atm-1) }
$$

Supplier

$\mathrm{O}_{2}$

$$
\mathrm{CO}_{2}
$$

$\begin{array}{llc}1.2 & 103 & 3.0103 \\ 6.5 & 103 & 500103 * \\ 13 & 103 & 150103 \\ 25 & 103 & 29103 \\ 200 & 103 & 204103\end{array}$
ICI, Dublin, Ireland ELF Atochem, Franc Dupont, France Courtaulds Packaging, Bristol, England ried out using $1 \mathrm{~mL}$ of macerated sample and $9 \mathrm{~mL}$ aliquots peptone water. The drop-and-spread technique was used whereby $0.1 \mathrm{~mL}$ of each dilution was spread in duplicate using a sterile glass spreader. The media used were de Man, Rogosa and Sharpe (MRS) for lactic acid bacteria, plate count agar for total counts, violet red bile agar for coliforms, and malt extract agar for yeasts and molds (Oxoid manual). Media were prepared and incubated as directed by the manufacturer (Oxoid supplied by B.M. Browne, Cork, Ireland). Duplicate and control samples were prepared for each sample and only counts of 30 to 300 colony forming units (cfu) were considered. The entire experiment was repeated 3 times.

\section{Statistical analysis}

All data were subjected to analysis of variance (ANOVA) and a least significant difference multicomparison test to determine significant differences between treatments (Shamaila and others 1992). Significance of differences was represented as $p<0.05$ termined using a WPA CD300 digital $\mathrm{pH}$ meter (WPA, Saffron Walden, England).

\section{Gas analysis of packs}

The atmospheric gases within the stored packs were measured throughout storage. Using an airtight syringe, gas $(10 \mathrm{~mL})$ was drawn from the pack and through the $1 \mathrm{~mL}$ sample loop of the gas chromatograph (Gow-Mac, Shannon, Ireland), which was fitted with a CTR1 column (Alltech, Deerfield, III., U.S.A.) These packs were sampled in duplicate, and the whole experiment repeated 3 times.

\section{Measurement of $\mathrm{pH}$}

Product $(100 \mathrm{~g})$ was blended for $2 \mathrm{~min}$ with $100 \mathrm{~mL}$ distilled and deionized water $(\mathrm{pH} 7)$. The $\mathrm{pH}$ of the macerate was determined using a WPA CD300 digital $\mathrm{pH}$ meter (WPA, Saffron Walden, England).
Ulrich R. 1975. Controlled atmosphere storage 2. Physiological and practical considerations. In: Pantastico B, editor. Postharvest Physiology, Handling and Utilization of Tropical and Subtropical Fruits and Vegetables. London: Academic Press. p 186-200. Wiley RC. 1994. Preservation methods for minimally processedrefrigerated fruits and vegetables. In: Wiley RC, editor. Minimally Processed Refrigerated Fruits and Vegetables. New York: Chapman and Hall. p 66-134. 